\title{
Penetrating Scrotal Injuries: A War Time Experience in a Civilian Setup
}

\author{
Ammar Fadil Abid ${ }^{1 *}$ (D), Naimet Naoum² \\ ${ }^{1}$ Department of Uro-surgery, Medical College, Al-Mustansiriyah University, Al-Yarmouk Teaching Hospital, Baghdad, Iraq; \\ ${ }^{2}$ Consultant Urologist, Medical College, Al-Mustansiriyah University, Al-Yarmouk Teaching Hospital, Baghdad, Iraq
}

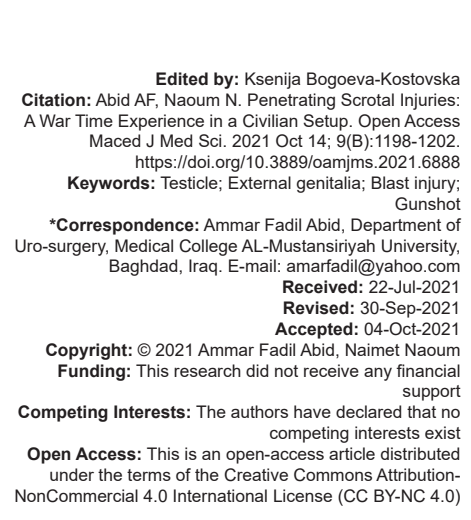

\section{Introduction}

Although injuries to the external genitalia are typically not in and of themselves life-threatening, yet they are commonly associated with other potentially lifethreatening injuries. Severe injuries to the genital and/or urinary structures can result in sexual dysfunction, urinary symptoms, infertility, and mental health problems [1], [2].

The genitourinary (GU) tract is involved in approximately $10 \%$ of all traumas, and up to $40-60 \%$ of all penetrating $\mathrm{GU}$ injuries involve the external genitalia. In civilian life trauma, the incidence of scrotal or testicular injury remains low $<1 \%$ [3], [4].

During the late $20^{\text {th }}$ century, body armor modifications as well as a shift in weapon use from predominantly high-velocity rounds to explosive munitions, likely resulted in shift from internal GU injuries (renal and bladder) to genital injuries becoming more predominant [2], [5].

Most of the GU injury reports of the Iraqi conflict have been limited to records of the battlefield injuries amongst coalition troops [6], [7], [8], [9].
On the other hand, civil violence has been escalating throughout the country since the beginning of the war in March 2003, and Iraqi civilian victims were daily exposed to violent acts everywhere across the country. The reports on $\mathrm{GU}$ injuries from the Iraqi sources were very limited [10], [11], [12], [13].

We aimed in this study to present our experience with penetrating scrotal injuries involving the testes, trying to highlight a possible role for a nonperative management of selected cases.

\section{Patients and Methods}

We reviewed retrospectively all-penetrating scrotal injuries presented to Alyarmook teaching hospital for the period between January 2009 and November 2015, including only those injured victims who reached the hospital alive.

Patients were initially triaged and evaluated in the emergency department (ED), and urologists were 
usually involved in managing the GU injuries. Unstable patients especially those with multi-organ injuries needed urgent operative treatment after preliminary resuscitation in the $E D$, while stable patients were admitted to complete their management in the hospital.

Patients' charts reviewed regarding their demographic data including age, status being civilian or military, and married or single. We documented as well the cause of injury (bullets vs. explosive devices), laterality, associated injured organs, and type of management performed whether operative or non-operative conservative approach. Operative management included either orchiectomy whether unilateral or bilateral, or suturing and repair to salvage the injured testis (es).

Conservative management was tried for scrotal injuries that were treated with no surgical intervention. Patients treated conservatively were selected after being clinically examined by the urologist, and evaluated by ultrasonic scrotal doppler. If the patient was stable, and the ultrasound did not show a significant Tunica Albugenia break nor a big hematoma was identified, then this patient would be admitted, and a serial clinical and ultrasonic examinations would be followed to make sure of the resolution of his injury, and absence of further complications.

Surgical care of polytrauma patients involving the genitalia, or those with confined scrotal and testicular injuries, was done according to the damage control surgical resuscitation protocols and the AUA Uro-trauma guidelines. Operations were done as an emergency or urgent procedure depending on the patient's triage status [14], [15].

Post-operative complications were recorded while in-patient and after a follow-up period of at least 1 month. Patients who had sustained bilateral testicular loss began testosterone replacement therapy as soon as possible after being discharged.

Categorical data were expressed as percentages, and continuous data as means and SD. Chi square and Fisher exact tests were used for statistical comparison of categorical groups, while one - way Anova and independent t-tests used for statistical comparison of continuous data. Level of significance was set at $(p<0.05)$.

\section{Results}

Thirty-one penetrating scrotal injuries were identified, including 34 injured testicles, 3 (9.6\%) patients had bilateral testicular injuries. Fourteen $(45.2 \%)$ injured testes were distributed equally on both right and left sides.

The patients' mean age was 34.35 years ( \pm 12.89 SD) ranging (18-70 years). Majority of the patients $(61.3 \%)$ were younger than 30 years old. Most of the victims $24(77.4 \%)$ were civilians, and 20 of them $(64.5 \%)$ were unmarried.

Explosive devices were the cause of injury in 23 patients $(74.2 \%)$ Figure 1, while bullets were the cause in the remaining 8 patients $(25.8 \%)$ Figure 2.

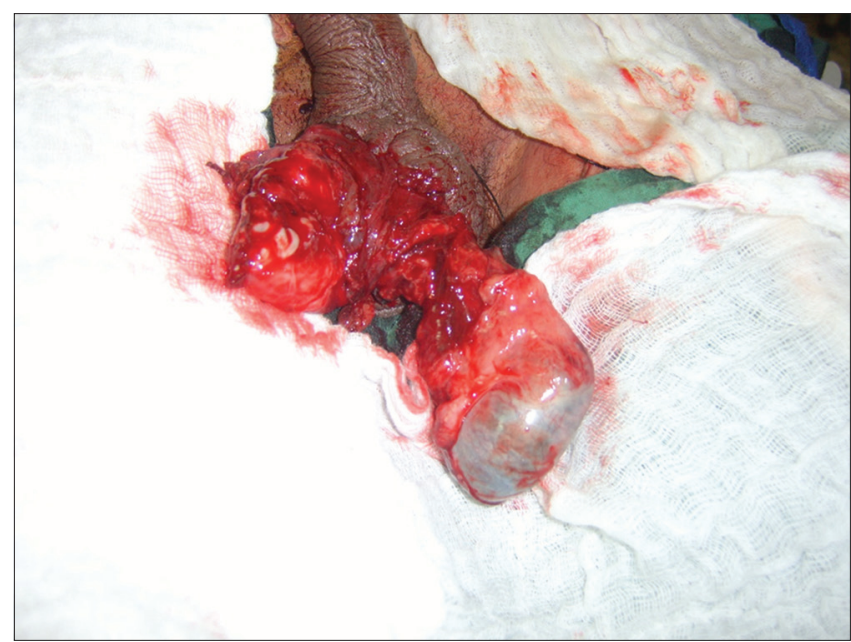

Figure 1: Blast injury of external genitalia after cleaning

Orchidectomy needed to be done in 17 (50\%) testicles, while 11(32.4\%) testes were explored and repaired by suturing. Bilateral orchidectomy was done in the three patients who had sustained bilateral injuries.

Six cases $(17.6 \%)$ were treated conservatively without any surgical intervention, $4(66.7 \%)$ of them were caused by bullet injuries. The overall testicular salvage rate was (50\%).

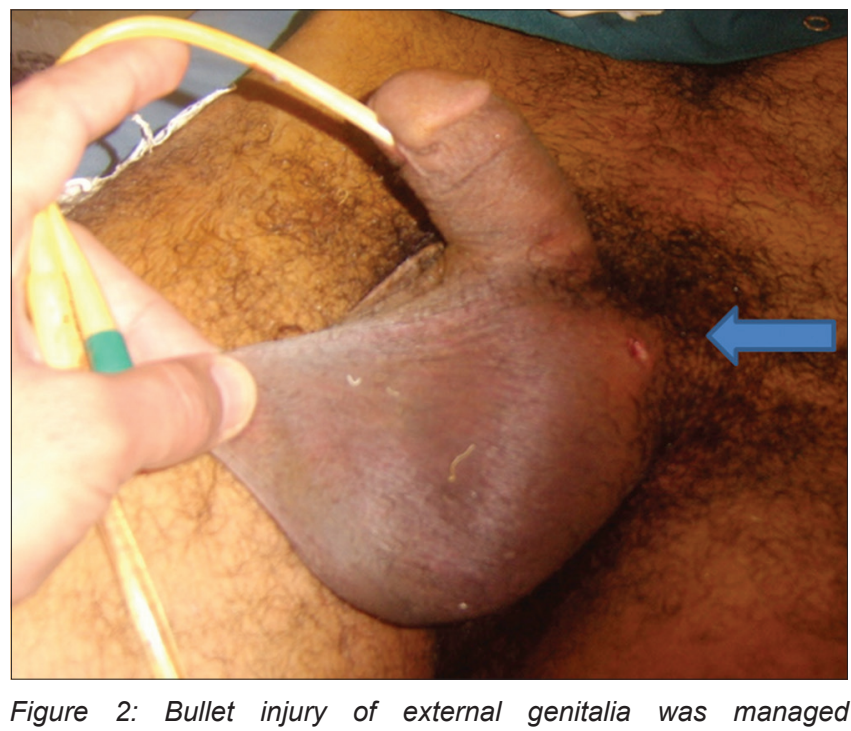
conservatively

Twenty-one patients (68\%) had associated injuries, mostly fractures in 15 patients (48.4\%), followed by bowel injuries in 7 (22.6\%), and associated GU injuries (Penile, urethral, and bladder) in 6 (19.3\%) patients (Figure 3).

Complications occurred in 10 (32.2\%) patients, with 2 mortalities, bleeding requiring blood transfusion 


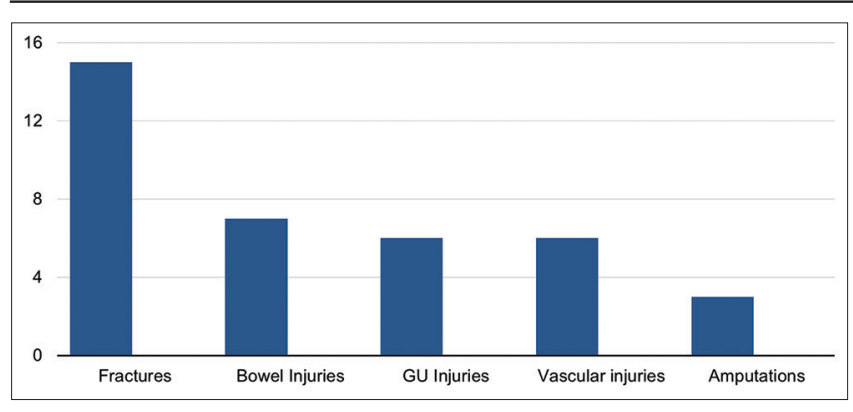

Figure 3: Concomitant injuries in 31 penetrating external genitalia injury

in five patients, and infection-causing sepsis with longer hospitalization in three patients. The 2 death incidents occurred on the surgical table due to severe multi-organ injuries.

We didn't find a statistical relationship between the age of the patients and the cause of their injuries, nor the type of management performed ( $p=0.551$ and $p=0.255)$. The age was not found as well statistically related to the presence of associated injuries $(p=0.272)$.

Trending towards more orchidectomies in blast injuries without statistical significance was found $(p=0.069)$. We could not find a significant relationship between the cause of the injury and laterality or the presence of associated injuries $(p=0.723, p=0.074)$.

No statistical relation was found between the presence of associated injuries and type of management performed $(p=0.316)$.

\section{Discussion}

During U.S. troop involvement in Iraq and Afghanistan, a number of factors determined by the weapon energy level and the individual's protective equipment, converged and ultimately resulted in the frequency of genital injuries increasing to a level never before reported in the history of war. The majority of injuries sustained during these conflicts were caused by ground-based explosive mechanisms and frequently resulted in a unique injury pattern to dismounted troop known as dismounted complex blast injury, which involves multiple extremity amputations, pelvic fractures, and extensive genital/perineal wounds. Explosions now represent the most common mechanism of injury (78\%) and death (63\%) on the modern battlefield [16].

During the 3-year study at Balad, air force theatre hospital 2005-2008, (71.5\%) of the operative procedures involved the external genitalia. Eighty percent of the scrotal trauma in UK forces in Iraq and Afghanistan 2003-2009, were caused by improvised explosive devices [9], [17].

In our study, most of the testicular injuries $(74.2 \%)$, occurred as a result of explosive devices.
This coincides with other literatures which studied the military and civilian injuries during the Iraq invasion period [1], [2], [6], [9], [11], [16], [17].

Phonsombat et al, reviewed retrospectively the records of 110 civilian patients with penetrating injuries to the external genitalia in San Francisco between 1977 and 2006 and found that half of the patients injured by gunshot wounds (GSW), which constituted only $25.8 \%$ of our cases [3].

Likely due to the demographic norms of military service, the majority (81.4-95.6\%) of the penetrating GU injury victims, were young adults $<30$ years old. This is higher than the $(61.3 \%)$ incidence in our study, as the majority were civilians [2].

Bilateral testicular injuries in $(9.6 \%)$ of our patients, show less incidence than reported by others (14.8-26.5\%) [1], [9].

Our salvage rate of the injured testes was $50 \%$. This rate varies in different studies depending on the combat theatre setup, which will ultimately reflect the type of weapons used and the severity of the injuries.

In a civilian setup, testes injured by GSW were salvaged in $50-75 \%$ of cases, and in $86 \%$ of a single study cases, where the injuries occurred mainly by explosives [3], [11], [18].

Military testicular salvage rates varies from $10 \%$ to $52 \%$ in reports from the Vietnam era, when injuries are typically the result of high-velocity projectiles or landmine shrapnels. With improvements in military medical services, salvage rates increased in the US and UK military operations in Iraq and Afghanistan to reach $(51.1-74.4 \%)$ in different literatures [1], [17].

The TOUGH project for epidemiology of $\mathrm{GU}$ Injuries among Male U.S. service members in Iraq and Afghanistan, reported $67.6 \%$ salvage rate, while Williams et al., reported $59.3 \%$ testicular salvage rate among the UK troops injured by explosives in Iraq and Afghanistan [2], [9].

Significant atrophy may nevertheless occur Later on in repaired testes that may adversely affect future fertility. Future non-obstructive azoospermia and atrophy were noticed in blast pelvic injuries even without obvious testicular involvement. These findings may question the realistic concept of salvage rates [2], [16].

We managed to treat six injured testes conservatively depending on clinical and imaging judgment. Serial clinical and Doppler ultrasonic examinations were done to make sure that the initially limited testicular injury is stable and resolving.

The American and the European urology guidelines indicate that penetrating injuries to the scrotum require surgical exploration with debridement of 
non-viable tissue, though the European guidelines also mentioned conservative management in hematoceles smaller than three times the size of the contralateral testes [14], [19].

Some literatures documented severe testicular injuries with only minimal scrotal wall lacerations, and GU surgeons did observe that the visible appearance of the scrotum was not a reliable predictor of the presence or absence of testicular injury. Therefore, scrotal exploration became a routine practice for many, to stage penetrating scrotal trauma [1], [17].

Nevertheless, other literatures did recommend non-surgical treatment in a selected group of penetrating penile and scrotal injuries, with the use of doppler ultrasonography to determine the extent of the vascular damage [3], [20].

We think that the conservatively treated patients in our study will definitely need a longer follow-up period, and the method itself needs more studies to be standardized.

Disfigured genital injuries in these young men, especially those unmarried, will, unfortunately, impact their future sexual and reproductive life. They need to be managed in a collaborative multidisciplinary approach, with the involvement of a clinical psychologist well versed in sexual medicine to help for the long-term psychological rehabilitation. In this aspect, we may suggest as well, especially for those with bilateral testicular injuries, that sperm retrieval and cryopreservation for future in vitro fertilization, be part of their management plans. These techniques have been already in practice, and in their way to become the standard of care in treating such injuries [2], [15], [21].

This study has its inherited limitations being retrospective, together with the small sample size, and the short follow-up period. Trauma literatures traditionally have poor follow-up, limiting thus the outcome analysis. Most of the trauma studies pointed to these limitations [3].

\section{Conclusions}

Genital injuries are rarely life-threatening, but they often become the male patient's chief concern once the acute injury phase resolves. Management of GU injuries continues to be a challenging task. In our study, we managed to salvage $50 \%$ of the injured testes. Non-surgical treatment is feasible in selected patients, a method that needs further study and longer follow-up.

\section{References}

1. Waxman S, Beekley A, Morey A, Soderdahl D. Penetrating trauma to the external genitalia in operation Iraqi freedom. Int J Impot Res. 2009;21(2):145-8. https://doi.org/10.1038/ ijir.2008.59

\section{PMid:19020522}

2. Janak JC, Orman JA, Soderdahl DW, Hudak SJ. Epidemiology of genitourinary injuries among male U.S. Service members deployed to Iraq and Afghanistan: Early findings from the trauma outcomes and urogenital health (TOUGH) project. J Urol. 2017;197(2):414-9.

PMid:27506692

3. Phonsombat S, Master VA, McAninch JW. Penetrating external genital trauma: A 30-year single institution experience. J Urol. 2008;180(1):192. https://doi.org/10.1016/j.juro.2008.03.041

PMid:18499189

4. Grigorian A, Livingston JK, Schubl SD, Hasjim BJ, Mayers D, Kuncir E, et al. National analysis of testicular and scrotal trauma in the USA. Res Rep Urol. 2018;10:51-6. https://doi. org/10.2147//ru.s172848

PMid:30128306

5. Hudak SJ, Morey AF, Rozanski TA, Fox CW Jr. Battlefield urogenital injuries: Changing patterns during the past century. Urology. 2005;65(6):1041-6. https://doi.org/10.1016/j. urology.2004.11.031

PMid:15913731

6. Edmond L. Paquette: Genitourinary trauma at a combat support hospital during operation Iraqi freedom: The impact of body armor. J Urol. 2007;177(6):2196-9. https://doi.org/10.1016/j. juro.2007.01.132

PMid: 17509316

7. Owens BD, Kragh JF Jr., Wenke JC, Macaitis J, Wade CE, Holcomb JB. Combat wounds in operation Iraqi Freedom and operation Enduring Freedom. J Trauma. 2008;64(2):295-9. https://doi.org/10.1097/ta.0b013e318163b875

PMid:18301189

8. Serkin FB, Soderdahl DW, Hernandez J, Patterson M, Blackbourne L, Wade CE. Combat urologic trauma in US military oversees contingency operations. J Trauma. 2010;69(1):175-8. PMid:20622614

9. Williams RJ, Fries CA, Midwinter M, Lambert AW. Battlefield scrotal trauma: How Should it be managed in a deployed military hospital? Injury. 2013;44(9):1246-9.

PMid:23587211

10. Petros FG, Santucci RA, Al-Saigh NK. The incidence, management, and outcome of penetrating bladder injuries in civilians resultant from armed conflict in Baghdad 2005-2006. Adv Urol. 2009;2009:275634. https://doi.org/10.1155/2009/275634 PMid:19360111

11. Al-Azzawi IS, Koraitim MM. Lower genitourinary trauma in modern warfare: The experience from civil violence in Iraq. Injury. 2014;45(5):885-9. https://doi.org/10.1016/j.injury.2014.01.005 PMid:24485550

12. Alsaigh NK, Alharoob IS. Renal injuries in penetrating abdominal trauma: Iraqi experience of Alyarmouk teaching hospital. J Urol. 2007;177(4):55. https://doi.org/10.1016/ s0022-5347(18)30427-0

13. Ammar $A F$, Hussein $H L$. Ureteral injuries from gunshots and shells of explosive devices. Urol Ann. 2010;2(1):17-20. https:// doi.org/10.4103/0974-7796.62920

PMid:20842252

14. Morey AF, Brandes S, Dugi DD, Armstrong JH, Breyer BN 
Broghammer JA, et al. Urotauma: AUA guideline. J Urol. 2014;192(2):327-35. https://doi.org/10.1016/j.juro.2014.05.004 PMid:24857651

15. Balzano FL, Balzano Steven J. Military genitourinary injuries: Past, present, and future. Transl Androl Urol. 2018;7(4):646-52. https://doi.org/10.21037/tau.2018.04.05 PMid:30211054

16. Cannon JW, Hofmann LJ, Glasgow SC, et al. Dismounted complex blast injuries: A comprehensive review of the modern combat experience. J Am Coll Surg. 2016;223(4):652-64.e8. PMid:27481095

17. Hudac SJ, Hakim S. Operative management of wartime genitourinary injuries at Balad Air Force theater hospital, 2005 to 2008. J Urol. 2009;182(1):180-3. https://doi.org/10.1016/j. juro.2009.02.150

PMid:19450817

18. Brandes SB, Buckman RF, Chelsky MJ, Hanno PM
External genitalia gunshot wounds: A ten-year experience with fifty-six cases. J Trauma. 1995;39(2):266. https://doi. org/10.1097/00005373-199508000-00013

PMid:7674395

19. Kitrey ND, Djakovic N, Hallscheidt $P$, et al. EAU guidelines on urological trauma. In: European Association of Urology Pocket Guidelines. Arnhem, Netherlands: European Association of Urology EAU; 2020. p. 374-9.

20. Fackler ML. Civilian gunshot wounds and ballistics: Dispelling the myths. Emerg Med Clin North Am. 1998;16(1):17-28. https:// doi.org/10.1016/s0733-8627(05)70346-1

PMid:9496312

21. Sharma DM, Bowley DM. Immediate surgical management of combat-related injury to the external genitalia. J R Army Med Corps. 2013;159(1):i18. https://doi.org/10.1136/ jramc-2013-000023

PMid:23631321 